\title{
ОПЫТ МОЛОДЕЖНЫХ ПОЛЕВЫХ ШКОЛ В ИЗУЧЕНИИ ПАМЯТНИКОВ ГОРОДСКОЙ АРХЕОЛОГИИ
}

\author{
(C) 2021 г. В.С. Беляева
}

Автором анализируются результаты интеграции объектов археологии в современную социокультурную среду города. Выделены особенности развития археологических полевых школ до начала XXI века и приведены причины, изменившие политику государства в отношении привлечения молодежи к археологической и исторической деятельности. Обоснована перспективность проведения археологических полевых молодежных школ в историческом городе. На основе опыта проведения археологических полевых школ в исторических городах России выделяются формы и методы популяризации объектов археологии, педагогические и специальные научные технологии раскрытия информационного историко-культурного потенциала археологических древностей для молодежной аудитории (школьников, студентов, волонтеров), а так же особенности каждой из описанных школ.

Ключевые слова: археологические полевые школы, архитектурно-археологическая школа, охрана памятников города, просветительская деятельность среди молодежи.

\section{EXPERIENCE OF YOUTH FIELD SCHOOLS IN THE STUDY OF MONUMENTS OF URBAN ARCHAEOLOGY}

\section{S. Belyaeva}

The author analyses the results of the integration of archaeology sites into the modern sociocultural city environment. The peculiarities of the development of archaeological field schools until the beginning of the 21 st century are highlighted, and the reasons that changed the state policy in terms of the involvement of the youth in archaeological and historical activities are outlined. The reasons for the prospects of conducting archaeological field youth schools in the historical city are described. The forms and methods of popularization of archaeological sites, pedagogical and special scientific technologies for revealing the historical and cultural information potential of archaeological antiquities for a youth audience (schoolchildren, students, volunteers), as well as the features of each of the described schools, are given on the basis of the experience of archaeological field schools in historical cities of Russia.

Keywords: archaeological field schools, architectural and archaeological school, protection of city monuments, educational activities among the youth.

Археологические полевые школы являются далеко не новым феноменом в современной образовательной деятельности, история их берёт своё начало с 30-х гг. XX в. (Жук, 2017, с. 101). «Археологическая полевая школа» - это форма практической деятельности молодежи (студентов и школьников) в составе археологических экспедиций, которая предваряется или сопровождается теоретической подготовкой в сфере археологии и памятниковедения на базе различных образовательных, научных организаций и учреждений культуры» (Беляева, 2020, с. 166).

Изначально целями проведения таких школ были:

- подготовка новых археологических кадров для страны разного уровня квалификации;

- общение и совместная деятельность молодежи и научной интеллигенции;
- самореализация молодыми людьми своих собственных потребностей в творческой деятельности, возможность утвердиться в среде сверстников, младших и взрослых, другими словами, самоутвердиться в обществе, возможность проявить и развить свои собственные способности и таланты;

- использование заинтересованных физически здоровых людей в сельских археологических экспедициях.

С 2000-х годов и по настоящее время археологические полевые школы в России получили новый виток развития. Он связан как с государственной поддержкой историко-педагогических инициатив в сфере археологии, так и с осознанием необходимости расширения знаний молодёжи в сфере памятниковедения и охраны городских памятников. Повысился общественный интерес к археологическим школам со стороны их потенциальных орга- 
низаторов (преподаватели, работники музея, практикующие археологи и т. д.). Начиная с этого времени, именно практикующие археологи заинтересовались практикой проведения археологических школ не только на сельских памятниках, но и городских, благодаря чему можно говорить о формировании нового особого направления в проведении археологических школ - популяризации городской археологии, и большой связи АШ со сферой охраны памятников.

На современном этапе развития практики археологических школ исторический город представляется одним из наиболее перспективных мест для их проведения, поскольку сосредотачивает на памятнике археологии и в непосредственной близости множество музеев, архитектурных памятников, уже раскопанных и музеефицированных археологических городских объектов. Участие в городских раскопках молодежи является бесценным вкладом в дело сохранения археологического наследия исторических городов, так как культурный слой городов является наиболее трудозатратным для исследования.

Многие из археологических школ, которые проводятся на памятниках городской археологии, становятся ежегодными, продолжающимися несколько полевых сезонов. Обычно базой таких школ становятся научные экспедиции ведущих вузов и институтов с многолетними научными традициями проведения археологических работ в том или ином древнерусском городском центре. Можно назвать такие известные школы, как Школа археологического кружка ВолГУ (г. Волгоград), Тверская молодежная археологическая школа «ПОЛЕ» (г. Тверь, ТвГУ), Старорусская археологическая школа (г. Старая Русса), летняя полевая школа Новгородской археологической экспедиции, летняя школа по архитектурной археологии Архитектурно-археологической экспедиции Санкт-Петербургского государственного университета и т. д.

Одним из показательных примеров городской школы можно считать ежегодную летнюю полевую школу Новгородской археологической экспедиции (организаторы школы - МГУ и ИА РАН). Так, в 2019 году такая школа была организована на Троицком раскопе, куда были приглашены 4 группы волонтеров (96 человек) - студентов и школьников из
Москвы, Санкт-Петербурга, Екатеринбурга (Полевая школа Новгородского..., 2019, электронный ресурс). Работая на Троицком раскопе, в древнем Людином (иначе - Гончарском) конце Новгорода, участники археологической школы приобщались к новгородской истории при помощи практической деятельности: учились расчищать древние постройки, перебирать культурный слой и извлекать из него средневековые предметы, знакомились с методами археологических раскопок. В сезоне 2019 г. на Троицком раскопе при участии волонтеров полевой школы была собрана значительная коллекция индивидуальных находок (около 1500 предметов), характеризующая различные стороны жизни и быта средневековых новгородцев. В программу школы входили также лекции об археологии Новгорода, его богатейшей материальной культуре, берестяных грамотах и музыкальных древностях. Обширная экскурсионная программа познакомила участников проекта с уникальными архитектурными и историческими памятниками города и окрестностей, многие из которых включены в список ЮНЕСКО и являются объектами всемирного культурного наследия (Полевая школа Новгородской..., 2019, электронный ресурс).

В 2020 году получила развитие летняя школа по архитектурной археологии в рамках Архитектурно-археологической экспедиции Санкт-Петербургского государственного университета. В раскопках памятников средневековой новгородской архитектуры участвовали 34 волонтёра из разных городов России и США (Летняя Школа СПбГУ..., 2019, электронный ресурс). Их внимание было сосредоточено на памятниках средневековой архитектуры в пригородном новгородском Николо-Липенском монастыре (церковь Николы на Липне, 1292 год) и в Великом Новгороде (церковь Ильи Пророка на Славне, XII-XV вв.). Наряду с полевой работой (устранение некачественных результатов реставрации, установление реального фундамента памятника) руководители и постоянные сотрудники экспедиции читали лекции и вели практические занятия с волонтёрами: учили основам ведения архитектурно-археологических работ, полевой графической фиксации, обработке находок. Студенты, школьники не только участвовали в процессе раскопок и 
переборки культурного слоя, но и трудились в качестве лаборантов, получая новые навыки и умения. Работа в экспедиции дала участникам проекта уникальную возможность глубокого погружения в историю архитектурного наследия Великого Новгорода.

Также участникам школы посчастливилось копать в самом сердце Великого Новгорода - на расположенном в Детинце Владычном дворе. Крупнейшим открытием стало обнаружение гражданской постройки, датирующейся концом XII - первой третью XIV в. В ходе работ 2020 г. удалось зафиксировать южную стену здания и его юго-восточный угол, что позволило создать частичную реконструкцию постройки. В XIV в. на ее основаниях было возведено новое здание, вероятно, церковь Рождества Христова на сенях, фрагменты стен которой также были найдены в ходе работ экспедиции (Летняя архитектурно-археологическая школа, 2020, электронный ресурс).

Существуют археологические школы со смешанной целевой аудиторией из студентов и школьников. Например, на базе Института истории, международных отношений и социальных технологий Волгоградского государственного университета с октября 2006 года работает «Археологический кружок» (Археологический кружок, б. г., электронный ресурс).

Основной целью «Археологического кружка ВолГУ» является проведение тематических заседаний по вопросам археологии, антропологии, этнологии и археозоологии, городской археологии, которые помогают учащимся общеобразовательных учреждений Волгоградской области, а также аспирантам и молодым ученым ознакомиться с теоритическими вопросами относительно процессов, которые происходили на территории Нижнего Поволжья и Волго-Донского междуречья в прошлом (Археологический кружок, б. г., электронный ресурс).

В ходе обучения происходит налаживание контактов между слушателями школы (ученики 7-11 классов школы и лица до 35 лет) и руководителями археологических экспедиций из Волгоградской области и других регионов России для дальнейшего участия в полевых исследованиях, в том числе на городских памятниках (Археологический кружок, б. г., электронный ресурс).
Одним из показательных примеров городской школы с многоплановой структурой можно считать Тверскую археологическую школу «ПОЛЕ», которая действует в Тверском госуниверситете с 2018 года при поддержке Фонда «История Отечества» Российского исторического общества (Тверская молодёжная археологическая, б. г., электронный ресурс). Работа археологической полевой школы проходит с мая по август и включает в себя два этапа: теоретический (лекции и семинары археологов и историков ТвГУ и приглашенных специалистов) и практический (выездные сельские и городские стационарные экспедиции, экскурсии). Участие принимают школьники 8-11 классов и студенты вузов. Проводится конференция по практическим итогам полевого сезона. Материалы конференций представлены в виде электронных сборников статей. Особое значение в программе школы отводится городскому этапу - спасательным археологическим раскопкам в г. Твери до начала строительства на территории объектов археологического наследия - средневековых посадов, в границах распространения культурного слоя XVI-XIX вв. Так, в 2019 году участники археологической школы получили возможность поучаствовать в раскопках Затверецкого посада г. Твери, смогли научиться основным методам археологических раскопок и инновационным приемам ведения работ.

Старорусская археологическая школа в 2019 году была проведена на основе спонсорской поддержки, собранной на интернет-платформе Planeta.ru. В очередной летней археологическая школе «Старая Русса - Пятницкий раскоп» приняли участие волонтеры, студенты и школьники, многие из которых из малообеспеченных семей. Посредством участия в раскопках средневекового города они смогли приобрести практические навыки и знания по археологии и истории России, а некоторые определились и с будущей профессией историка-археолога (Археологическая школа в Старой, б. г., электронный ресурс).

Как показано выше, археологические школы, которые занимаются изучением и сохранением памятников городской археологии, включают разные виды деятельности - учебную, экспедиционную, экскурсионно-туристическую, камеральную, музейную, 
научно-исследовательскую. Финансирование таких школ может быть на основе самообеспечения, грантовым, государственным, хоздоговорным, спонсорским, смешанным. Среди участников преобладают студенты высших учебных заведений и (или) школьники. Форма проведения школы - очная. К результатам работы школ можно отнести полученные знания и умения обучающихся в сфере археологии, истории и охраны памятников; новые знакомства со сверстниками и с ведущими учёными; практический результат в виде изученного памятника, написанной статьи, выступления на итоговой конференции археологической школы.

Можно также отметить, что при проведении городских археологических школ формируются сходные формы и методы популяризации объектов городской археологии, педагогические и специальные научные технологии раскрытия информационного историко-культурного потенциала археологических древностей для молодежной аудитории.

Основные формы и методы популяризации археологии в рамках городских полевых школ:

- проведение лекций об основах археологической деятельности, а также о важности защиты археологического наследия, особенностях археологических и архитектурных памятников города и региона;

- проведение пеших экскурсий по городу, музейных экскурсий по экспозициям и специализированным выставкам, связанным с культурным наследием региона;

- проведение археологических изысканий на памятниках городской археологии.

При использовании данных форм и методов важным представляется разнообразие педагогических технологий как для популяризации археологической деятельности, так и для обучения молодежи основам профессио- нально сложных научных технологий в ходе проведения археологических полевых школ.

Специальные научные технологии включают в себя обучение участников школ методологии ведения археологических раскопок: от снятия балластных отложений до расчистки сооружений, фиксации и описи находок. Значимость данных технологий заключается в том, что участники школ во время процесса обучения понимают всю многогранность, а значит и историческую, общественную значимость сохранения памятников, не только видимых над поверхностью земли, но и тех, что находятся под землёй. Также благодаря археологическим раскопкам участники школ расширяют свои знания по истории, культуpe, быте, планировке города прошлых столетий, благодаря чему формируют реальный образ эпохи. В связи с новым направлением в системе археологических школ - архитектурной археологией, складывается и особая направленность на обучение заинтересованных молодых людей в сфере обнаружения, изучения и реставрации, консервации архитектурных памятников древности. Данный факт влечёт за собой и особое увеличение в обучении блока информации о сохранении архитектурного наследия городов.

Таким образом, археологические городские школы являются достаточно эффективным способом просветительской деятельности в области охраны памятников среди молодых людей. Данная форма является наиболее продуктивной для включения в систему сохранения культурного наследия, поскольку теоретическая деятельность в них всегда закрепляется практической, ставит школьников и студентов в положение активных авторов, благодаря чему данный вид временной занятости может в дальнейшем стать делом их жизни, побудит продолжать обучение в данной сфере.

\section{ЛИТЕРАТУРА}

Археологическая школа в Старой Руссе. // Planeta: Коллективное финансирование идей. URL: https://planeta.ru/campaigns/archrussa (дата обращения: 10.01.2020).

Археологический кружок ВолГУ. URL: https://volsu.ru/struct/institutes/iimost/archeology/ (дата обращения: 10.05.2020).

Беляева В.С. История развития археологической полевой школы в России // Путь в науку: материалы международной научной конференции молодых ученых исторического факультета Тверского государственного университета. / Сост., ред. Т.Г. Леонтьева, Ю.В. Степанова. Тверь: Тверской государственный университет, 2020. С. 166-170. 
Жук А.В. Ленинградская археология второй половины 1930 г. глазами молодого человека // Вестник Омского университета. Серия «Исторические науки». 2017. № 7. С. 97-110.

Летняя Школа СПбГУ по архитектурной археологии: сезон 2019 года. URL: https://fond.historyrussia. org/novosti/letnyaya-shkola-spbgu-po-arkhitekturnoj-arkheologii-sezon-2019-goda.html (дата обращения: 06.12.2020).

Летняя архитектурно-археологическая школа СПбГУ: сезон 2020. URL: https://fond.historyrussia. org/novosti/letnyaya-arkhitekturno-arkheologicheskaya-ekspeditsiya-spbgu-sezon-2020.html (дата обращения: 06.12.2020).

Полевая школа Новгородской археологической экспедиции на Троиицком раскопе. 2019. URL: https://fond.historyrussia.org/arkheologicheskie-ekspeditsii-i-issledovaniya/polevaya-shkola-novgorodskojarkheologicheskoj-ekspeditsii-na-troitskom-raskope.html (дата обращения: 06.12.2020).

Тверская молодёжная археологическая школа «ПОЛЕ». URL: https://sites.google.com/mail.ru/poletver (дата обращения: 10.01.2020).

\section{Информация об авторе:}

Беляева Виктория Сергеевна, Тверской государственный университет (г. Тверь, Россия); belyaewa.vicka2014@yandex.ru

\section{REFERENCES}

Arkheologicheskaia shkola v Srapoi Russe (Archaeological School in Staraya Russa). Available at: https:// planeta.ru/campaigns/archrussa (accessed: 10.01.2020) (in Russian).

Arkheologicheskii kruzhok VolGU (Archaeological Group in the Volgograg State University). Available at: https://volsu.ru/struct/institutes/iimost/archeology/ (accessed: 10.05.2020) (in Russian).

Belyaeva, V. S. 2020. In Leont'eva, T. G., Stepanova, Yu. V. (eds.). Put'v nauku (Path to Science). Tver: Tver State University, 166-170 (in Russian).

Zhuk, A. V. 2017.. In Vestnik Omskogo universiteta (Bulletin of the Omsk University) (7), 97-110 (in Russian).

Letniaia Shkola SPbGU po arkhitekturnoi arkheologii: sezon 2019 goda (Saint Petersburg State University Summer School in Architectural Archaeology: the 2019 Season). Available at: https://fond.historyrussia.org/ novosti/letnyaya-shkola-spbgu-po-arkhitekturnoj-arkheologii-sezon-2019-goda.html (accessed: 06.12.2020) (in Russian).

Letniaia Shkola SPbGU po arkhitekturnoi arkheologii: sezon 2020 goda (Saint Petersburg State University Summer School in Architectural Archaeology: the 2020 Season). Available at: https://fond.historyrussia.org/novosti/letnyaya-arkhitekturno-arkheologicheskaya-ekspeditsiya-spbgu-sezon-2020.html (accessed: 06.12.2020) (in Russian).

2019. Polevaia shkola Novgorodskoi arkheologicheskoi ekspeditsii na Troiitskom raskope (Field School of the Novgorod Archaeological Expedition at the Troitsky Excavation Site). Available at: https://fond.historyrussia.org/arkheologicheskie-ekspeditsii-i-issledovaniya/polevaya-shkola-novgorodskoj-arkheologicheskojekspeditsii-na-troitskom-raskope.html (accessed: 06.12.2020) (in Russian).

Tverskaia molodezhnaia arkheologicheskaia shkola "POLE" ("POLE" Tver Youth Archaeological School). Available at: https://sites.google.com/mail.ru/pole-tver (accessed: 10.01.2020) (in Russian).

\section{About the Author:}

Belyayeva Victoria S. Tver State University. Zhelyabov Str., 33 Tver, 170100, Russian Federation; belyaewa.vicka2014@yandex.ru 